\title{
Sensitive Measurement of Polyethylene Glycol-Modified Proteins
}

BioTechniques 30:396-402 (February 2001)

Nu-man Tsai, Tian-Lu Cheng, and Steve R. Roffler

Institute of Biomedical

Sciences, Academia Sinica, Taipei, Taiwan

\begin{abstract}
An IgM monoclonal antibody (AGP3) against polyethylene glycol (PEG) was used to assay PEG-modified proteins by ELISA. PEG-modified $\beta$-glucuronidase could be measured at concentrations as low as 15 $\mathrm{ng} / \mathrm{mL}$, corresponding to $750 \mathrm{pg}(1.8 \mathrm{fmol})$ of conjugate. This ELISA should be generally applicable to all PEG-modified proteins because AGP3 binds the backbone of the PEG chain independent of the linker used for PEG attachment.
\end{abstract}

\section{INTRODUCTION}

Recombinant proteins are increasingly being employed for the therapy of a wide variety of diseases. Many of the proteins in clinical development are modified by the covalent attachment of methoxypolyethylene glycol $(1,3,13,17$, 22), a flexible linear polymer containing repeating $\mathrm{O}-\mathrm{CH}_{2}-\mathrm{CH}_{2}$ subunits (11). Polyethylene glycol (PEG)-modified proteins often exhibit prolonged circulation half-lives $(6,7)$ and reduced proteolytic cleavage $(4,27)$. PEG modification has also been shown to reduce the immunogenicity of enzymes (5), antibodies (21), toxins (31), and recombinant human proteins (19). Reduction of immunogenicity can be important for clinical applications because even recombinant human proteins can induce humoral immune responses $(2,14)$.

Clinical development of PEG-modified proteins requires pharmacokinetic measurements in animals and patients. Ideally, the concentration of intact PEG-modified protein should be measured. Simple methods to measure intact PEG-protein conjugates, however, are not available. The concentration of the protein can be measured by immunological, biochemical, or functional assays, and the attachment of PEG can be verified by nuclear magnetic resonance (NMR) (18) or chemical $(16,29)$ methods. These methods, how ever, cannot be employed for complex samples such as serum. Methods that directly measure PEG concentration are relatively insensitive $(10,15,24)$.

We have developed a monoclonal antibody (mAb AGP3) that specifically binds to PEG (9). In this report, we investigated whether AGP3 could be used to measure the concentration of PEG-modified proteins by ELISA.

\section{MATERIALS AND METHODS}

\section{Reagents}

Methoxypolyethylene glycol succinimidyl propionate [molecular weight (MW) $5 \mathrm{kDa}$ ] was obtained from Fluka Chemie (Buchs, Switzerland). PEG-disuccinimidyl succinamide (MW 3.4 $\mathrm{kDa}$ ) and methoxypolyethylene glycol succinimidyl propionate (MW 2 and 20 $\mathrm{kDa})$ were purchased from Shearwater Polymers (Huntville, AL, USA). Seph$\operatorname{adex}^{\circledR}$ G-25 (Amersham Pharmacia Biotech Asia Pacific, Quarry Bay, Hong Kong) and Ultrogel AcA 22 gels as well as methoxypolyethylene glycol tresylate and chicken egg white lysozyme were from Sigma (St. Louis, MO, USA). A HiLoad 16/60 Superdex ${ }^{\circledR} 75$ column was from Amersham Pharmacia Biotech Asia Pacific. Succinimidyl-6-(biotinamido) hexanoate (NHS-LC-biotin) was obtained from Pierce Chemical (Rockford, IL, USA).

\section{Antibodies}

$1 \mathrm{E} 8$, an $\mathrm{IgG}_{1} \mathrm{mAb}$ against $\beta$-glucuronidase $(\beta \mathrm{G})$, and AGP3, an IgM antibody against PEG, were generated as described (9). Streptavidin-horseradish peroxidase (HRP) was from Serotec (Oxford, UK). HRP-conjugated goat 
anti-mouse $\operatorname{IgM} \mu$-chain antibody (HRP-GAM $\mu$-chain) and HRP-conjugated goat anti-mouse Ig (HRP-GAM) were from Organon Teknika (Durham, NC, USA).

\section{PEG Modification of $\beta G$}

Recombinant $E$. coli-derived $\beta G$ was produced and purified as described (7). $\beta G$ or lysozyme were passed through a $2.6 \times 30-\mathrm{cm}$ Sephadex G-25 column equilibrated with $0.1 \mathrm{M}$ borate buffer, $\mathrm{pH} 8.0$, and concentrated by ultrafiltration to $3 \mathrm{mg} / \mathrm{mL}$. Methoxypolyethylene glycol succinimidyl propionate [at $w / w$ ratios (PEG: $\beta G$ ) of $40: 1$, 20:1, and 4:1 for PEG with MW of 20, 5 , and $2 \mathrm{kDa}$, respectively] in $0.1 \mathrm{M}$ borate buffer, $\mathrm{pH} 8.0(150 \mathrm{mg} / \mathrm{mL})$ was added to $\beta G$ and mixed for $2 \mathrm{~h}$ at room temperature. $\beta \mathrm{G}-\mathrm{PEG}$ refers to the preparation of $\beta \mathrm{G}$ modified with $5-\mathrm{kDa}$ PEG chains. Lysozyme was similarly modified, except that 1:20 (PEG: lysozyme) molar ratios were employed to obtain lysozymes modified with only one PEG chain. One-tenth volume of a saturated solution of glycine was added to stop the reaction. Unreacted PEG was removed by gel filtration on a $2.5 \times$ 100-cm Ultrogel AcA 22 column or a HiLoad 16/60 Superdex 75 column. Columns were eluted with PBS at 15 $\mathrm{mL} / \mathrm{h}$. Relevant fractions containing PEG-modified proteins were pooled, concentrated by ultrafiltration to 1 $\mathrm{mg} / \mathrm{mL}$, and stored at $-80^{\circ} \mathrm{C}$. $\beta \mathrm{G}$ was cross-linked with PEG-di-succinimidyl succinamide ( $3.3 \mathrm{mg}$ PEG/mg $\beta \mathrm{G}$ ) in a similar manner to produce $\beta \mathrm{G}-\mathrm{PEG}$ $\beta G$. Protein concentrations were determined by the bicinchoninic acid assay (Pierce Chemical) with bovine serum albumin (BSA) used as the reference protein. PEG groups were estimated by measuring amine groups before and after PEG modification with fluorescamine (29).

\section{Purification of AGP3}

AGP3 ascites obtained from pristane-primed eight-week-old BALB/c female mice was centrifuged at $5000 \times$ $g$ for $10 \mathrm{~min}$ to remove debris. Ascites fluid $(5 \mathrm{~mL})$ was passed through a 5 mL Sephadex G-25 column equilibrated with PBS and then purified by gel filtration on a $2.5 \times 100-\mathrm{cm}$ Ultrogel AcA 22 column eluted with PBS at 15 $\mathrm{mL} / \mathrm{h}$. Fractions containing AGP3 were collected, concentrated by ultrafiltration to $1-2 \mathrm{mg} / \mathrm{mL}$, and stored at $-80^{\circ} \mathrm{C}$. Yields of $5-6 \mathrm{mg}$ AGP $3 / \mathrm{mL}$ ascites were typically achieved.

\section{Biotinylation of AGP3}

AGP3 $(1 \mathrm{mg} / \mathrm{mL})$ in $0.1 \mathrm{M}$ borate buffer, $\mathrm{pH}$ 8.0, was mixed with a 25-fold molar excess of NHS-LC-biotin for $1 \mathrm{~h}$ at room temperature to produce AGP3biotin. One-tenth volume of a saturated solution of glycine was added to stop the reaction before aliquots were stored at $-80^{\circ} \mathrm{C}$. The antigen-binding activity of AGP3-biotin was determined by ELISA in 96-well microplates coated overnight with $1 \mu \mathrm{g} /$ well $\beta$ G-tPEG (20 $\mathrm{mg}$ methoxypolyethylene glycol tresylate/mg $\beta \mathrm{G}$, prepared as described in Reference 9). Plates were blocked $1 \mathrm{~h}$ at $37^{\circ} \mathrm{C}$ with $2 \%$ skim milk in PBS before $50 \mu \mathrm{L} /$ well samples of AGP3 or AGP3biotin in dilution buffer $(0.5 \%$ BSA, $0.05 \%$ Tween ${ }^{\circledR} 20$ in PBS) were added to the wells for $1 \mathrm{~h}$ at room temperature. Plates were washed six times with PBSTB $(0.05 \%$ BSA, $0.1 \%$ Tween 20 in PBS), and $50 \mu \mathrm{L} /$ well of either streptavidin-HRP (1:1000) or HRP-GAM $\mu$ chain $(1: 1000)$ in dilution buffer were added for $1 \mathrm{~h}$ at room temperature. The plates were washed six times, and 100 $\mu \mathrm{L} /$ well ABTS substrate $[0.4 \mathrm{mg} / \mathrm{mL}$ 2,2'-azino-di(3-ethylbenzthiazoline-6sulfonic acid), $0.003 \% \mathrm{H}_{2} \mathrm{O}_{2}, 100 \mathrm{mM}$ phosphate-citrate, $\mathrm{pH} 4.0$ ] were added for $30 \mathrm{~min}$ at room temperature. $\mathrm{Ab}$ sorbance $(405 \mathrm{~nm})$ of wells was measured in a Molecular Devices (Sunnyvale, CA, USA) microplate reader.

\section{AGP3 Immunoblot}

$\beta \mathrm{G}(0.5 \mu \mathrm{g}), \beta \mathrm{G}-\mathrm{PEG}(0.5 \mu \mathrm{g})$, and $\beta G-P E G-\beta G \quad(2 \mu \mathrm{g})$ were electrophoresed on a $3 \%-12.5 \%$ gradient SDS polyacrylamide gel and transferred to nitrocellulose paper as described (9). The paper was blocked for $1 \mathrm{~h}$ with $5 \%$ skim milk in PBS and then incubated for $2 \mathrm{~h}$ at room temperature with 0.5 $\mu \mathrm{g} / \mathrm{mL} \mathrm{mAb} 1 \mathrm{E} 8$ or AGP3 in dilution buffer. Blots were washed three times with PBS-TM and incubated for $1 \mathrm{~h}$ at room temperature with HRP-GAM 
(1:1000 in dilution buffer). Blots were washed three times before bands were visualized by ECL ${ }^{\circledR}$ detection according to the manufacturer's instructions (Pierce Chemical).

\section{AGP3 ELISA}

Maxisorp $^{\mathrm{TM}}$ 96-well microplates (Nalge Nunc International, Roskilde, Denmark) were coated with $50 \mu \mathrm{L} /$ well of AGP3 $(200 \mu \mathrm{g} / \mathrm{mL})$ in PBS for $3 \mathrm{~h}$ at $37^{\circ} \mathrm{C}$ or in $35 \mathrm{mM} \mathrm{NaHCO}, 15 \mathrm{mM}$ $\mathrm{Na}_{2} \mathrm{CO}_{3}, \mathrm{pH} 9.3$, overnight at $4^{\circ} \mathrm{C}$. Plates were blocked with $2 \%$ skim milk in PBS overnight and washed twice with PBST $(0.05 \%$ Tween 20 in PBS) before serial dilutions of $\beta \mathrm{G}$ or $\beta \mathrm{G}$ PEG (50 $\mu \mathrm{L}$ in dilution buffer) were added to wells for $1.5 \mathrm{~h}$ at room temperature. Plates were washed six times with PBST, and $50 \mu \mathrm{L} /$ well AGP3-biotin $(20 \mu \mathrm{g} / \mathrm{mL}$ in dilution buffer) were added for $1.5 \mathrm{~h}$ at room temperature. Plates were again washed with PBST, and $50 \mu \mathrm{L} /$ well streptavidin-HRP (1:1000) were added for $1 \mathrm{~h}$ at room temperature. Plates were washed before $100 \mu \mathrm{L} /$ well ABTS substrate was added for 5-30 min at room temperature. Absorbance $(405 \mathrm{~nm})$ of wells was measured in a microplate reader. The effect of serum on the AGP3 ELISA was examined by performing the assay in the presence of $10 \%$ serum isolated from healthy BALB/c mice.

\section{RESULTS}

Methoxypolyethylene glycol succinimidyl propionate (MW $5 \mathrm{kDa}$ ) was covalently attached to an enzyme $(\beta \mathrm{G})$ to form $\beta \mathrm{G}-\mathrm{PEG}$. An average of 6.8 PEG chains was attached to each 70$\mathrm{kDa}$ subunit of the $\beta \mathrm{G}$ tetramer. The electrophoretic mobility of $\beta \mathrm{G}-\mathrm{PEG}$ (Figure 1A, lane 3) was slower than unmodified $\beta G$ (Figure 1A, lane 2) as determined by SDS PAGE followed by immunoblotting with a mAb against $\beta G$, demonstrating successful conjugation of PEG to $\beta \mathrm{G}$. $\beta \mathrm{G}$ was also successfully cross-linked with PEG to form $\beta \mathrm{G}-\mathrm{PEG}-\beta \mathrm{G}$ (Figure 1A, lane 1). $\beta G-P E G-\beta G$ does not contain a terminal methoxy group on the PEG chain. AGP3 bound $\beta$ G-PEG (Figure $1 \mathrm{~B}$, lane 3 ) and $\beta G-P E G-\beta G$ (Figure $1 B$, lane 1) but not unmodified $\beta \mathrm{G}$ (Figure $1 \mathrm{~B}$, lane 2 ). Binding of AGP3 to $\beta$ G-PEG- $\beta G$ shows that AGP3 binds to the backbone of PEG rather than the methoxy group present at the terminal of methoxypolyethylene glycol.

AGP3 was examined as the basis of an ELISA for the detection of PEGmodified proteins. AGP3 was modified with a 25-fold molar excess of NHSLC-biotin to produce AGP3-biotin. AGP3-biotin retained the same antigenbinding activity to $\beta \mathrm{G}$-tPEG as AGP3 in ELISA using HRP-goat anti-mouse $\operatorname{IgM} \mu$-chain antibody for detection (Figure 2). Detection of antibody binding to $\beta G-P E G$ with streptavidin-HRP showed that AGP3-biotin, but not AGP3, could be detected (Figure 2), demonstrating that biotin was indeed incorporated into AGP3-biotin.

A sandwich ELISA was developed in which AGP3 was used for the capture antibody and AGP3-biotin was used as the detection antibody. Figure 3 shows that this assay could detect $\beta \mathrm{G}$ PEG at concentrations as low as 15 $\mathrm{ng} / \mathrm{mL}$, corresponding to $750 \mathrm{pg}$ conjugate in a $50-\mu \mathrm{L}$ sample. The assay only detected PEG-modified protein as shown by the lack of signal when unmodified $\beta G$ was assayed (Figure 3). The effect of serum on the ELISA was examined by adding $10 \%$ mouse serum to samples before the assay. The sensitivity of the assay was about the same as without serum (Figure 3).

To investigate the influence of PEG chain length on the sensitivity of the ELISA, PEG with nominal molecular weights of 20,5 , and $2 \mathrm{kDa}$ was covalently attached to $\beta \mathrm{G}$. The average degree of modification was 5.1, 7.1, and 11.4 PEG chains per subunit of the $\beta \mathrm{G}$ tetramer for PEG chains with MW of 20, 5, and $2 \mathrm{kDa}$, respectively. Figure $4 \mathrm{~A}$ shows that all the $\beta \mathrm{G}$ conjugates were modified with PEG as demonstrated by the reduced mobility of the conjugates. Measurement of conjugate concentrations by ELISA revealed that assay sensitivity increased for longer PEG chains (Figure 4B). Assay of $\beta G$ modified with 20-kDa PEG chains was about eight times more sensitive than $\beta \mathrm{G}$ modified with 5-kDa PEG chains, which in turn was about four times more sensitive than $\beta G$ modified with 2-kDa PEG chains.

To determine whether the ELISA assay could detect proteins modified with a single chain of PEG, lysozyme was modified with one PEG molecule with molecular weights of 2, 5, or $20 \mathrm{kDa}$. Purified lysozyme-PEG conjugates appeared as single bands on SDS polyacrylamide gels (Figure 5A), indicating that the conjugates were homogeneous 1:1 conjugates. The AGP3 ELISA could assay lysozyme modified with one molecule of 20-kDa PEG (Figure 5). No signal was detected, however,

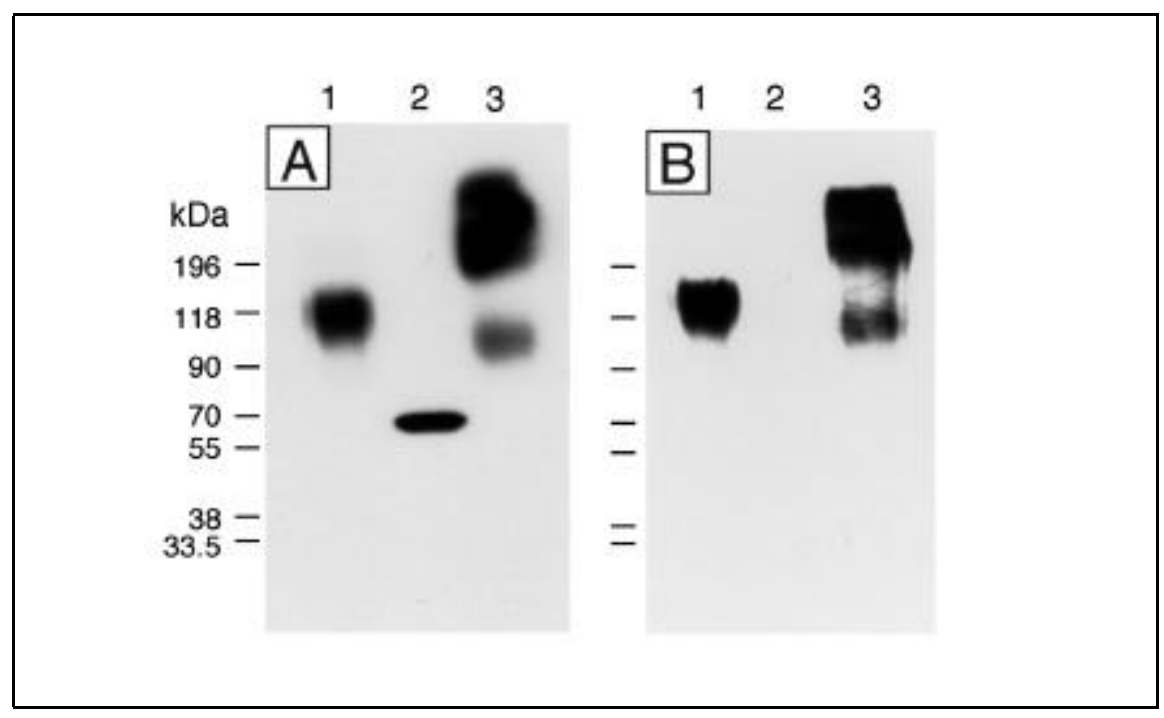

Figure 1. Immunoblot of PEG-modified proteins. Samples were electrophoresed on a 3\%-12.5\% reduced SDS polyacrylamide gel, transferred to nitrocellulose paper, and probed with mAb 1E8 (A) or AGP3 (B) as described in Materials and Methods. Lane 1, $\beta$ G-PEG- $\beta G$; lane 2, $\beta G$; lane 3, $\beta$ G-PEG. $\mathrm{kDa}$, molecular mass in thousands. 


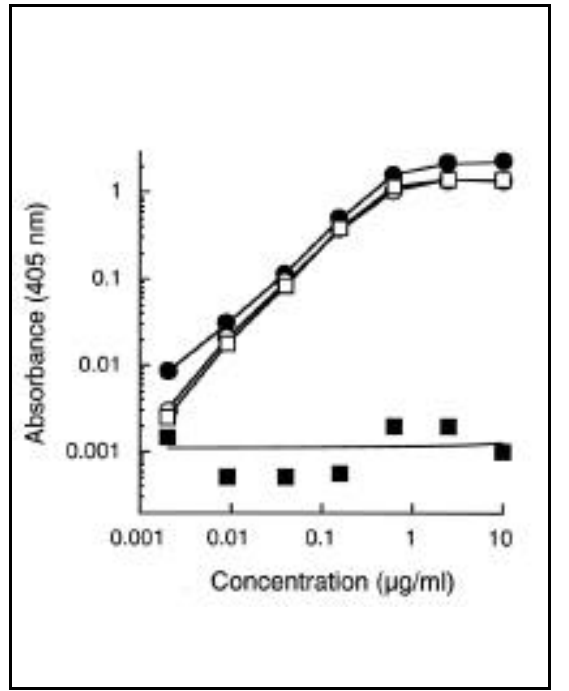

Figure 2. Activity of biotinylated AGP3. Serial dilutions of AGP3 (squares) or AGP3-biotin (circles) were assayed for binding to $\beta$ G-tPEG by ELISA. Antibody binding was detected with HRPGAM $\mu$-chain (open symbols) or HRP-streptavidin (closed symbols). The average absorbance values of duplicate determinations are shown.

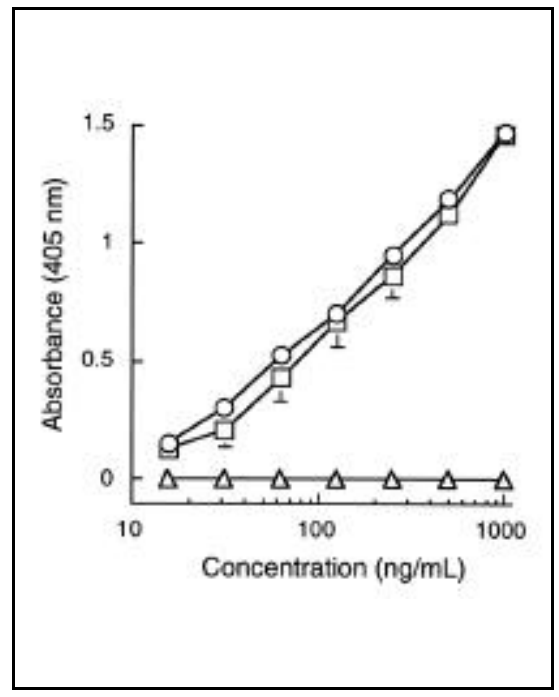

Figure 3. AGP3 ELISA. Serial dilutions of $\beta G$ $(\Delta)$ and $\beta$ G-PEG in PBS $(\mathrm{O})$ or PBS containing $10 \%$ mouse serum $(\square)$ were assayed by AGP3 ELISA as described in Materials and Methods. The mean absorbance values of triplicate determinations, read $30 \mathrm{~min}$ after addition of substrate, are shown. Bars, standard error. when lysozyme modified with a single chain of 2- or 5-kDa PEG was assayed (results not shown).

\section{DISCUSSION}

AGP3 is a murine $\operatorname{IgM} \mathrm{mAb}$ that was developed by immunizing mice with $\beta G$-PEG (9). We have previously shown that AGP3 can accelerate the clearance of PEG-modified immunoenzymes for antibody-directed enzyme prodrug therapy $(8,9)$. Previous studies also demonstrated that AGP3 binds to PEG rather than the linker used for conjugation (9). It was possible, however, that AGP3 bound to the terminal methoxy group of PEG. We found in the current study that AGP3 bound $\beta$ G-PEG- $\beta$ G, a conjugate that does not contain a terminal methoxy group, showing that AGP3 binds to the repeating subunits of the PEG backbone. This finding indicates that multi- 
ple AGP3 mAbs can bind to a single PEG chain and prompted us to examine whether AGP3 could be used in a sandwich ELISA for the detection of PEGmodified proteins.

An ELISA was developed in which AGP3 was employed for both the capture and detection of protein-PEG conjugates. AGP3 could be modified with a 25-fold molar excess of biotin without loss of antigen-binding activity. The ELISA detected a PEG-modified protein ( $\beta G$-PEG) with a detection limit of around $15 \mathrm{ng} / \mathrm{mL}$. This corresponds to 1.8 fmol $\beta \mathrm{G}-\mathrm{PEG}[\beta \mathrm{G}$ tetramer modified with 27 PEG $(5 \mathrm{kDa})$ molecules with an overall MW of $415 \mathrm{kDa}$, indicating that the detection sensitivity should be adequate for most PEG-modified proteins. The sensitivity of the assay depended on the length of the PEG chains attached to $\beta G$; longer PEG chains resulted in increased assay sensitivity. This is likely due to the binding of multiple AGP3 antibodies to the PEG backbone, allowing amplification of the signal as PEG chain length increases. The ability of the ELISA assay to detect lysozyme modified with a single 20-kDa PEG molecule must also rely on the capability of both the capture and detection AGP3 antibodies to bind to the same PEG chain. The assay could not detect lysozyme modified with a single PEG molecule of 2 or 5 $\mathrm{kDa}$, which is likely due to steric hindrance between the capture and detecting antibodies. The ELISA was insensitive to $10 \%$ serum, suggesting that this method can be used to quantify PEGconjugate concentrations in serum sam ples for pharmacological and pharmacokinetic studies. It should be noted that the assay might overestimate the plasma concentration of heterogeneous conjugate preparations since conjugates containing fewer PEG chains will clear faster (30). This effect is expected to be more pronounced for small conjugates that contain few PEG chains.

There are currently no methods to directly measure low concentrations of intact PEG conjugates for pharmacological studies. Conjugates can be indirectly measured by first radiolabeling the protein $(7,32)$ or PEG $(23)$, but radioisotopes pose safety concerns and require special handling. Functional assays can be used to measure the concentration of the protein component of conjugates $(9,12)$, but no information is provided about the stability of the attached PEG chains. Methods that measure the num ber of PEG molecules attached to a protein $(16,29)$ require that purified conjugates be employed, which is difficult to achieve in pharmacokinetic studies. Methods that directly measure the concentration of PEG are relatively insensitive. Colorimetric methods based on complex formation between barium-iodide and PEG require that proteins are first removed and have detection limits of 1-5 $\mu \mathrm{g}$ PEG (10). A colorimetric method based on partitioning of a chromophore present in aqueous ammonium ferrothiocyanate reagent can be employed for complex protein mixtures but has a detection limit of $1-5 \mu \mathrm{g}$ PEG $(24,25)$. HPLC can quantify PEG with a

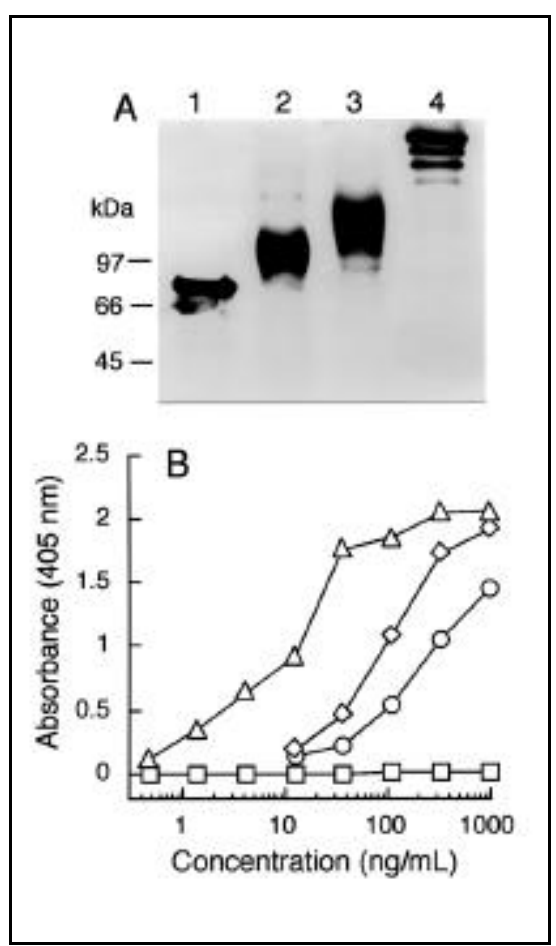

Figure 4. Effect of PEG chain length on ELISA sensitivity. (A) $\beta G$ (lane 1) or $\beta G$ modified with PEG possessing average molecular weights of 2 (lane 2), 5 (lane 3), or 20 (lane 4) kDa were electrophoresed on a reducing 3\%-12.5\% gradient SDS polyacrylamide gel and stained with Coomassie ${ }^{\circledR}$ Blue R-250. kDa, molecular mass in thousands. (B) Serial dilutions of $\beta G$ ( $\square$ ) and $\beta G$ modified with PEG possessing average molecular weights of $2(\mathrm{O}), 5(\diamond)$, or $20(\Delta) \mathrm{kDa}$ were assayed by AGP3 ELISA as described in Materials and Methods. The mean absorbance values of triplicate determinations, read 5 min after addition of substrate, are shown. Bars, standard error. detection limit of $1-5 \mu \mathrm{g} / \mathrm{mL}(20,28)$. Phase partitioning can be used to measure PEG, but the assay sensitivity is about $1 \mu \mathrm{g}$ PEG (15). Finally, polyclonal antibodies against PEG can detect the presence of $1 \mu \mathrm{g} / \mathrm{mL}$ PEG in PEG-modified proteins (26). The newly developed ELISA can measure approximately 250 pg PEG in PEG- $\beta$ G [27 PEG (5 $\mathrm{kDa})$ chains per $\beta \mathrm{G}$ tetramer with an overall MW of $415 \mathrm{kDa}$ ], several orders of magnitude more sensitive than previous methods. In addition, the AGP3 ELISA does not require prior separation of PEG conjugates from complex mixtures, simplifying application to pharmacokinetic studies.

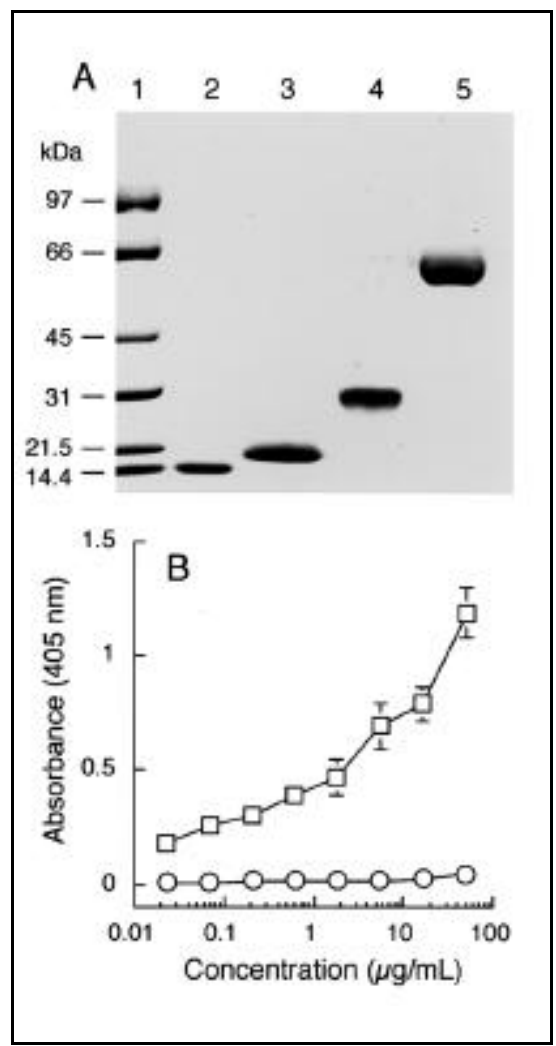

Figure 5. AGP3 ELISA of proteins with a single PEG chain. (A) Lysosyme (lane 2) or lysosyme modified with a single PEG chain possessing an average molecular weight of 2 (lane 3), 5 (lane 4), or 20 (lane 4) kDa were electrophoresed on a reducing $10 \%$ SDS polyacrylamide gel and stained with Coomassie Blue R250. Lane 1 shows molecular weight standards. $\mathrm{kDa}$, molecular mass in thousands. (B) Serial dilutions of lysosyme $(\mathrm{O})$ or lysosyme modified with a PEG chain of $20 \mathrm{kDa}(\square)$ were assayed by AGP3 ELISA as described in Materials and Methods. The mean absorbance values of triplicate determinations, read $5 \mathrm{~min}$ after addition of substrate, are shown. Bars, standard error. 
Given that the assay measures PEG rather than protein, the newly developed ELISA should be applicable to the measurement of any PEG-modified protein in complex mixtures. In addition, AGP3 can be used to probe the presence and size distribution of PEG conjugates on immunoblots. The sensitivity of the AGP3 ELISA should allow convenient measurement of PEG-conjugate pharmacokinetics for preclinical and clinical studies.

\section{ACKNOWLEDGMENTS}

This work was supported by Academia Sinica and grant no. NSC89-2320B001-017 from the National Science Council, Republic of China.

\section{REFERENCES}

1.Aguayo, A., J. Cortes, D. Thomas, S. Pierce, M. Keating, and H. Kantarjian. 1999. Com bination therapy with methotrexate, vincristine, polyethylene-glycol conjugated-asparaginase, and prednisone in the treatment of patients with refractory or recurrent acute lymphoblastic leukemia. Cancer 86:12031209.

2.Atkins, M.B., J.A. Gould, M. Allegretta, J.J. Li, R.A. Dempsey, R.A. Rudders, D.R. Parkinson, S. Reichlin, and J.W. Mier. 1986. Phase I evaluation of recombinant interleukin-2 in patients with advanced malignant disease. J. Clin. Oncol. 4:1380-1391.

3.Basser, R.L., J.E. Rasko, K. Clarke, J. Cebon, M.D. Green, S. Hussein, C. Alt, D. Menchaca et al. 1996. Thrombopoietic effects of pegylated recombinant human megakaryocyte growth and development factor (PEG-rHuMGDF) in patients with advanced cancer. Lancet 348:1279-1281.

4.Brinckerhoff, L.H., V.V. Kalashnikov, L.W. Thompson, G.V. Yamshchikov, R.A. Pierce, H.S. Galavotti, V.H. Engelhard, and C.L. Slingluff, Jr. 1999. Terminal modifications inhibit proteolytic degradation of an immunogenic MART-1(27-35) peptide: implications for peptide vaccines. Int. J. Cancer 83:326334.

5.Chaffee, S., A. Mary, E.R. Stiehm, D. Girault, A. Fischer, and M.S. Hershfield. 1992. IgG antibody response to polyethylene glycol-modified adenosine deaminase in patients with adenosine deaminase deficiency. J. Clin. Invest. 89:1643-1651.

6.Chapman, A.P., P. Antoniw, M. Spitali, S. West, S. Stephens, and D.J. King. 1999. Therapeutic antibody fragments with prolonged in vivo half-lives. Nat. Biotechnol. 17:780-783.

7.Cheng, T.L., B.M. Chen, L.Y. Chan, P.Y. Wu, J.W. Chern, and S.R. Roffler. 1997. Poly(ethylene glycol) modification of beta- glucuronidase-antibody conjugates for solidtumor therapy by targeted activation of glucuronide prodrugs. Cancer Immunol, Im munother. 44:305-315.

8.Cheng, T.L., B.M. Chen, J.W. Chern, M.F. Wu, and S.R. Roffler. 2000. Efficient clearance of poly(ethylene glycol)-modified immunoenzyme with anti-PEG monoclonal antibody for prodrug cancer therapy. Bioconj. Chem. 11:258-266.

9.Cheng, T.L., P.Y. Wu, M.F. Wu, J.W. Chern, and S.R. Roffler. 1999. Accelerated clearance of polyethylene glycol-modified proteins by anti-polyethylene glycol IgM. Bioconj. Chem. 10:520-528.

10.Childs, C.E. 1975. The determination of polyethylene glycol in gamma globulin solutions. Microchem. J. 20:190-192.

11.Delgado, C., G.E. Francis, and D. Fisher. 1992. The uses and properties of PEG-linked proteins. Crit. Rev. Ther. Drug Carrier Syst. 9:249-304.

12.Esslinger, H.U., S. Haas, R. Maurer, A. Lassmann, K. Dubbers, and $H$. Muller Peltzer. 1997. Pharmacodynamic and safety results of PEG-Hirudin in healthy volunteers. Thromb. Haemost. 77:911-919.

13.Fareed, J., D. Callas, D.A. Hoppensteadt, J.M. Walenga, and R.L. Bick. 1998. Antithrombin agents as anticoagulants and antithrombotics. Implications in drug development. Med. Clin. North Am. 82:569-586.

14.Gribben, J.G., S. Devereux, N.S. Thomas, M. Keim, H.M. Jones, A.H. Goldstone, and D.C. Linch. 1990. Development of antibodies to unprotected glycosylation sites on recombinant human GM-CSF. Lancet 335:434-437.

15.Guermant, C., J. Brygier, D. Baeyens Volant, M. Nijs, J. Vincentelli, C. Paul, and Y. Looze. 1995. Quantitative determination of polyethylene glycol based upon its salting out and partitioning of a dye into the resulting aqueous two-phase system. Anal. Biochem. 230:254-258.

16.Habeeb, A.F. 1966. Determination of free amino groups in proteins by trinitrobenzenesulfonic acid. Anal. Biochem. 14:328-336.

17.Harker, L.A. 1999. Physiology and clinical applications of platelet growth factors. Curr. Opin. Hematol. 6:127-134.

18.Jackson, C.J., J.L. Charlton, K. Kuzminski, G.M. Lang, and A.H. Sehon. 1987. Synthesis, isolation, and characterization of conjugates of ovalbumin with monomethoxypolyethylene glycol using cyanuric chloride as the coupling agent. Anal. Biochem. 165:114-127.

19. Katre, N.V. 1990. Immunogenicity of recom binant IL- 2 modified by covalent attachment of polyethylene glycol. J. Immunol. 144:209213.

20.Kinahan, I.M. and M.R. Smyth. 1991. High-performance liquid chromatographic determination of PEG 600 in human urine. J. Chromatogr. 565:297-307.

21.Kitamura, K., T. Takahashi, T. Yamaguchi, A. Noguchi, K. Takashina, H. Tsurumi, M. Inagake, T. Toyokuni, and S. Hakomori. 1991. Chemical engineering of the monoclonal antibody A7 by polyethylene glycol for targeting cancer chemotherapy. Cancer Res. 51:4310-4315.

22.Menzel, T., A. Schomburg, A. Korfer, M.
Hadam, M. Meffert, I. Dallmann, S. Casper, H. Kirchner, H. Poliwoda, and J. Atzpodien. 1993. Clinical and preclinical evaluation of recombinant PEG-IL-2 in human. Cancer Biother. 8:199-212.

23.Mullin, J.M., C.W. Marano, K.V. Laughlin, M. Nuciglio, B.R. Stevenson, and P. Soler. 1997. Different size limitations for increased transepithelial paracellular solute flux across phorbol ester and tumor necrosis factor-treated epithelial cell sheets. J. Cell Physiol. 171:226-233.

24.Nag, A., G. Mitra, and P.C. Ghosh. 1996. A colorimetric assay for estimation of polyethylene glycol and polyethylene glycolated protein using ammonium ferrothiocyanate. Anal. Biochem. 237:224-231.

25.Nag, A., G. Mitra, and P.C. Ghosh. 1997. A colorimetric estimation of polyethyleneglycol-conjugated phospholipid in stealth liposomes. Anal. Biochem. 250:35-43.

26. Richter, A.W. and E. Akerblom. 1983. Antibodies against polyethylene glycol produced in animals by immunization with monomethoxy polyethylene glycol modified proteins. Int. Arch. Allergy Appl. Immunol. 70:124-131.

27.Roseng, L., H. Tolleshaug, and T. Berg. 1992. Uptake, intracellular transport, and degradation of polyethylene glycol-modified asialofetuin in hepatocytes. J. Biol. Chem. 267:22987-22993.

28.Ryan, C.M., M.L. Yarmush, and R.G. Tompkins. 1992. Separation and quantitation of polyethylene glycols 400 and 3350 from human urine by high-performance liquid chromatography. J. Pharm. Sci. 81:350-352.

29.Stocks, S.J., A.J. Jones, C.W. Ramey, and D.E. Brooks. 1986. A fluorometric assay of the degree of modification of protein primary amines with polyethylene glycol. Anal. Biochem. 154:232-234.

30.Vanwetswinkel, S., S. Plaisance, Z. Zhi Yong, I. Vanlinthout, K. Brepoels, I. Lasters, D. Collen, and L. Jespers. 2000. Pharmacokinetic and thrombolytic properties of cysteine-linked polyethylene glycol derivatives of staphylokinase. Blood 95:936-942

31.Wang, Q.C., L.H. Pai, W. Debinski, D.J. FitzGerald, and I. Pastan. 1993. Polyethylene glycol-modified chimeric toxin composed of transforming growth factor alpha and Pseudomonas exotoxin. Cancer Res. 53:45884594.

32.Yabe, Y., M. Nishikawa, A. Tamada, Y. Takakura, and M. Hashida. 1999. Targeted delivery and improved therapeutic potential of catalase by chemical modification: combination with superoxide dismutase derivatives. J. Pharmacol. Exp. Ther. 289:1176-1184.

Received 10 March 2000; accepted 4 August 2000.

Address correspondence to:

Dr. Steve Roffler

Institute of Biomedical Sciences

Academia Sinica

Taipei, Taiwan

e-mail: sroff@ibms.sinica.edu.tw 